\title{
Stable isotope monitoring of benthic-planktonic coupling using salt marsh fish
}

\author{
Brian Fry ${ }^{1, *}$, Matthew Cieri ${ }^{2}$, Jeff Hughes ${ }^{3}$, Craig Tobias ${ }^{4}$, Linda A. Deegan ${ }^{5}$, \\ Bruce Peterson ${ }^{5}$
}

\begin{abstract}
${ }^{1}$ Department of Oceanography and Coastal Sciences, LSU, Baton Rouge, Louisiana 70803, USA
${ }^{2}$ Maine Department of Marine Resources, PO Box 8, McKnown Point Road, West Boothbay Harbor, Maine 04575, USA

${ }^{3}$ Department of Biological Sciences, Wellesley College, 106 Central Street, Wellesley, Massachusetts 02481, USA

${ }^{4}$ Department of Earth Sciences, University of North Carolina-Wilmington, Wilmington, North Carolina 28403, USA

${ }^{5}$ Ecosystems Center, Marine Biological Laboratory, Woods Hole, Massachusetts 02543, USA
\end{abstract}

\begin{abstract}
Salt marshes are important coastal ecosystems whose trophic function can be monitored with stable isotopes of abundant fish biosentinel species such as the mummichog Fundulus heteroclitus and the Atlantic silverside Menidia menidia. We compared movement patterns and feeding biology of these species in the summers of 1999 and 2000 in the Rowley River salt marsh estuary north of Boston, Massachusetts, USA. A ${ }^{15} \mathrm{~N}$ tracer addition experiment showed that fish of both species were more resident than transient, with mummichogs resident at scales of $1 \mathrm{~km}$ or less. Natural abundance stable isotope $\mathrm{C}, \mathrm{N}$, and $\mathrm{S}$ distributions showed that mummichogs feed more strongly in the benthic food web while silversides feed more in the planktonic food web, with \% benthic feeding respectively averaging $58 \pm 5$ and $32 \pm 3 \%$ (mean $\pm 95 \%$ confidence limit, CL). For both species, isotope results indicated considerable individual specialization in foraging behavior likely related to use of channel habitat versus use of the marsh. Power analysis showed that measuring 3 composite samples each comprising 10 to 15 individual fish should provide relatively low errors of $0.5 \%$ o $(95 \%$ CL) or less around stable isotope averages. Use of such composite samples in monitoring programs will allow detection of significant temporal and spatial changes in benthicplanktonic coupling for salt marsh ecosystems, as recorded in average fish diets. Analyzing some individual fish also is recommended to obtain more detailed information on fish food sources, feeding specializations, and end-member isotope values used in estimating importance of benthic and planktonic food sources.
\end{abstract}

KEY WORDS: Stable isotope analysis $\cdot$ Salt marsh $\cdot$ Fish $\cdot$ Monitoring $\cdot$ Power analysis $\cdot$ Benthic microalgae $\cdot$ Spartina

Resale or republication not permitted without written consent of the publisher

\section{INTRODUCTION}

The mummichog Fundulus heteroclitus and the Atlantic silverside Menidia menidia are 2 abundant salt marsh fish in New England estuaries along the US Atlantic coast (Gerking 1994, Murdy et al. 1997, Griffin \& Valiela 2001). The mummichog is a predominantly benthic-feeding fish that moves into shallow marsh habitats on higher tides (Kneib et al. 1980, D'Avanzo \& Valiela 1990), while the silverside is a predominantly plankton-feeding fish that is more restricted to chan- nels adjoining the marshes (Able \& Fahay 1998). The high abundance and contrasting feeding habits of these species make them interesting as possible biosentinels for marsh ecosystems that undergo changes for a variety of reasons, ranging from ditching for mosquito control to gradual submergence due to global sea level rise. For example, Talley (2000) and Wozniak et al. (2006) used carbon stable isotope distributions in Fundulus to evaluate the effectiveness of marsh restoration techniques, with successful restoration indicated by fish with similar isotope values in 
restored and reference sites. Stable isotope measurements thus can provide a way to assay ecosystem impairment and restoration. Because carbon, nitrogen, and sulfur stable isotopes in fish reflect a rather complex estuarine biogeochemistry and food web cycling of elements (Fry 2006), fish isotopes can provide an integrated view of marsh ecosystem status and are a potentially sensitive tool for estuarine assessments. Similar assessments of changing ecosystem dynamics recently have been proposed at the larger scales of continents and indeed the whole global biosphere using a combination of stable isotope measurements for microbes, mice, and birds (Williams et al. 2007). Historical assessments of ecosystem change also are being attempted with stable isotope measurements of lake biota (Schmidt et al. 2007).

We used a combination of $\mathrm{C}, \mathrm{N}$, and $\mathrm{S}$ (hereafter CNS) stable isotope measurements to better understand the feeding and movement biology of mummichogs and silversides. Several previous investigations have used a combination of CNS isotopes to study these species and broader estuarine food web dynamics (e.g. Wainright et al. 2000, Connolly et al. 2004, Dittel et al. 2006). For example, a previous study of a Cape Cod, Massachusetts, Spartina salt marsh showed that isotopes in bivalves recorded how the mix of planktonic and benthic foods changed along a spatial gradient from interior marsh to open bay waters (Peterson et al. 1985). Use of planktonic foods was indicated by a particular combination of CNS isotopes, with lower $\mathrm{C}$ stable isotope values and higher $\mathrm{N}$ and $\mathrm{S}$ stable isotope values indicating phytoplankton use, and conversely higher $\mathrm{C}$ isotope values and lower $\mathrm{N}$ and $\mathrm{S}$ stable isotope values indicating use of benthic food sources such as Spartina (Peterson et al. 1985) and benthic microalgae (Currin et al. 1995). Wozniak et al. (2006) recently showed that different salt marsh estuaries can produce different mixtures of isotope signals in fish, with the local mix of food isotope signals in part related to the extent of tidal mixing. Here we tested whether the strong triple isotope CNS marsh signal detected in older studies of relatively pristine Massachusetts and Georgia salt marsh ecosystems (Peterson et al. 1985, 1986, Peterson \& Howarth 1987) was also present in fish from the Rowley River system, a northern Massachusetts marsh that is strongly flushed by tides.

The Rowley River estuary is a sub-basin of the larger Plum Island Sound estuary that also includes the Parker River estuary. Previous CNS isotope investigations of the general food web in Plum Island Sound (Deegan \& Garritt 1997) analyzed only a few mummichogs and silversides, so that the fish isotope variation was incompletely characterized. A later investigation with ${ }^{15} \mathrm{~N}$-labeled nitrate added to the Parker River
(Hughes et al. 2000) also analyzed only a few fish. For monitoring and ecosystem assessment, it is important to know averages but also variability, and thus one of our aims was to characterize the variability of isotope distributions for the 2 fish species. This was done during the summer of 1999, when individuals of the 2 species were collected along the main axis of the Rowley River estuary, from a 'down-estuary' station $6 \mathrm{~km}$ from the ocean mouth of the estuary to a $13 \mathrm{~km}$ 'up-estuary' station near the freshwater terminus of the estuary at $15 \mathrm{~km}$. Individual fish were analyzed for CNS isotopes to characterize variability that might relate to individualized fish feeding preferences, with a null hypothesis that the 2 species have similar degrees of feeding specialization and similar isotope variation among individuals. Isotope averages for the 2 species were also calculated for several stations located along the freshwater-marine axis of the estuary, to test the null hypothesis of no change in isotopes and diets along the salinity gradient.

We also tested patterns of fish movement within a larger ${ }^{15} \mathrm{~N}$ tracer addition experiment (Tobias et al. 2003) that was conducted in mid-summer of 2000. During and after the labeling period, strong ${ }^{15} \mathrm{~N}$ enrichments were expected if fish were local in their movements and fairly resident, but little or low-level enrichment was expected for individuals and species that moved widely throughout the estuary. Overall, our study helps resolve the main controls of isotope variation in 2 important salt marsh fish species, and concludes with a statistical power analysis to help guide future efforts that use stable isotopes in fish biosentinel species to assess ecosystem-level changes in salt marsh trophic function.

\section{MATERIALS AND METHODS}

Sampling and isotope measurements. Two-person seines were used for fish collections at fixed locations along the estuary at $6,8,9.3,10.3,11,12$, and $13 \mathrm{~km}$ from the mouth of the estuary during 30 July to 3 August 1999 and during 20 June to 31 August 2000. Animals were placed in an ice bath at the time of collection, and then transported to the laboratory where they were frozen. Later processing included thawing and measuring total lengths and blotted wet mass, followed by dissection of white muscle tissue from the dorsal sides of fish. Muscle tissue was cleaned by rinsing in running tap water and was then placed in glass vials and allowed to soak for 15 to $60 \mathrm{~min}$ in deionized water to remove salt. The soak water was discarded, tissues were dried at $60^{\circ} \mathrm{C}$, and pulverized with a WigL-Bug automated grinder. Some stomach content samples were collected in 2000 to help track the ${ }^{15} \mathrm{~N}$ label 
addition into fish. In these cases, stomach contents from all individuals collected at each station were dissected out and pooled, rinsed with deionized water and allowed to settle, and then dried at $60^{\circ} \mathrm{C}$ for later ${ }^{15} \mathrm{~N}$ analysis.

Isotope values were measured for individual fish, and pooled stomach contents, with an automated system that included an elemental analyzer with an isotope ratio mass spectrometer for coupled measurements of C, N, and S isotope values (Barrie \& Prosser 1996, Brand 1996, Fry 2007). Splits of the same sample analyzed for $\mathrm{C}, \mathrm{N}$, and $\mathrm{S}$ isotope analyses usually agreed by $0.3 \%$ or better. Results are given in \%o units as $\delta^{13} \mathrm{C}$ versus Vienna Peedee Belemnite (VPDB), $\delta^{15} \mathrm{~N}$ versus air $\mathrm{N}_{2}$, and $\delta^{34} \mathrm{~S}$ versus Vienna Canyon Diablo Troilite (VCDT). Tank $\mathrm{CO}_{2}, \mathrm{~N}_{2}$, and $\mathrm{SO}_{2}$ gases calibrated with known standards were used as working reference materials in daily laboratory operation (Fry 2007).

Food sources. Isotope results were evaluated in several ways, including use of a 2-source isotope mixing model (Fry 2006) to estimate fish use of planktonic and benthic foods where $\%$ benthic $=100 \times\left(\delta_{\text {Observed }}-\right.$ $\left.\delta_{\text {Planktonic source }}\right) /\left(\delta_{\text {Benthic source }}-\delta_{\text {Planktonic source }}\right)$ and \% planktonic $=100-\%$ benthic. Plant and animal isotope values were used to estimate the source values using published plant and animal isotope data for the Rowley River estuary and the surrounding Plum Island ecosystem, with average source values calculated from Tables 1 \& 2, respectively, in Deegan \& Garritt (1997) and Fry (2007). Benthic source values were averages for benthic Spartina plants, and planktonic values were averages for plankton-feeding oysters, marsh mussels, blue mussels, and copepods. A 3.4\% trophic enrichment factor (Vander Zanden \& Rasmussen 2001) was added to the published prey $\delta^{15} \mathrm{~N}$ values to estimate $\delta^{15} \mathrm{~N}$ source values for fish; no adjustment for trophic enrichment was made to measured $\delta^{34} \mathrm{~S}$ or $\delta^{13} \mathrm{C}$ values (Peterson \& Fry 1987). The resulting source values fell along the main trend of the fish data (see Fig. 1), but isotope values for several mummichogs fell outside the range of these published source values, consistent with more extreme values in benthic source foods. Unsampled benthic algae could represent such source foods (Incze et al. 1982, Currin et al. 1995). To finalize the mixing model to include the possibility of such unmeasured foods, benthic source values were adjusted as indicated in Fig. 1 to the extreme isotope values of the Rowley mummichogs as the best available estimates of local benthic end-member foods. The final benthic and planktonic source values used in mixing models were respectively -11.8 and $-23.4 \%$ for $\mathrm{C}$ isotopes, 6.4 and $13.8 \%$ o for $\mathrm{N}$ isotopes, and -1.3 and $15.3 \%$ for $\mathrm{S}$ isotopes. A combined isotope value was also calculated to show the cumulative benthic versus

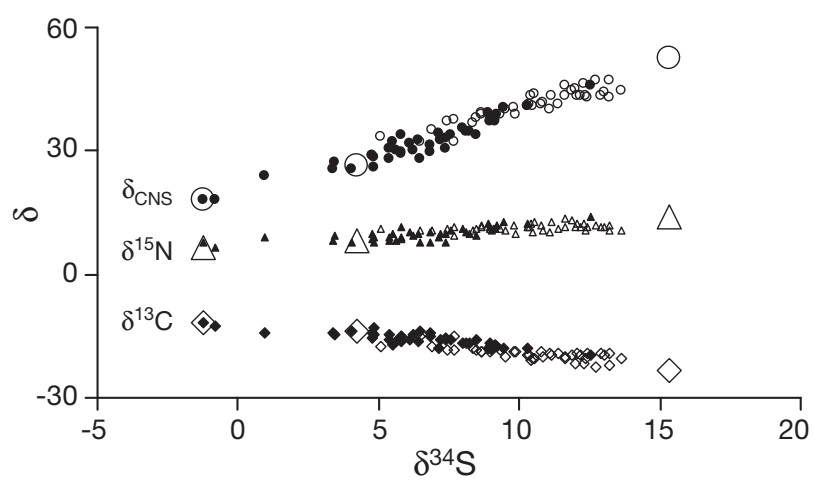

Fig. 1. Fundulus heteroclitus and Menidia menidia. Isotope data for individual fish, summer 1999. The linear relationships indicate 2-source mixing interpreted as benthic feeding versus planktonic feeding, with mummichog data (small closed symbols) representing more benthic feeding and silverside data (small open symbols) representing more planktonic feeding. $\mathrm{R}^{2}$ values for linear trends versus $\mathrm{S}$ isotopes were $0.79,0.56$, and 0.93 for $\delta^{13} \mathrm{C}, \delta^{15} \mathrm{~N}$, and $\delta_{\mathrm{CNS}}$ respectively. Large open symbols at right indicate planktonic sources used in mixing models, large open symbols in the middle represent benthic Spartina sources, and leftmost large open symbols indicate final benthic source values used in mixing models. Key to small symbols: circles $=\delta^{34} \mathrm{~S}$ $\times \delta_{\mathrm{CNS}}$ data, triangles $=\delta^{34} \mathrm{~S} \times \delta^{15} \mathrm{~N}$ data, and diamonds $=$ $\delta^{34} \mathrm{~S} \times \delta^{13} \mathrm{C}$ data

planktonic contrast represented by the combined CNS data: $\delta_{\mathrm{CNS}}=\delta^{34} \mathrm{~S}+\delta^{15} \mathrm{~N}-\delta^{13} \mathrm{C}$. It was necessary to subtract rather than add the $\mathrm{C}$ isotope values in this $\delta_{\mathrm{CNS}}$ value to give the overall contrast in benthic versus planktonic sources, because the $\mathrm{C}$ isotope contrasts were opposite in sign to the $\mathrm{N}$ and $\mathrm{S}$ contrasts, e.g. with planktonic sources lower in $\mathrm{C}$ isotopes but higher in $\mathrm{N}$ and $\mathrm{S}$ isotopes than benthic sources, so that adding the $\mathrm{C}$ isotope values would have underestimated the cumulative CNS contrast. Respective benthic and planktonic source values for the combined isotope value were 16.9 and 52.5\%. Mixing model estimates of benthic versus planktonic contributions were calculated for the $\mathrm{C}, \mathrm{N}$, and $\mathrm{S}$ isotopes separately and for the combined isotope value. In the mixing model estimates made with the combined $\delta_{\mathrm{CNS}}$ isotope value, the $\mathrm{C}, \mathrm{N}$, and $\mathrm{S}$ isotope data respectively accounted for 33,21 , and $46 \%$ of the overall separation between the benthic and planktonic sources.

Fish movement. Stable isotope values also were evaluated in terms of fish movement using ${ }^{15} \mathrm{~N}$ enrichment results associated with label addition from 11 July to 12 August, 2000. The local food web in the upper estuary from about 11 to $15 \mathrm{~km}$ was labeled by adding ${ }^{15} \mathrm{~N}$-labeled nitrate to the upper part of the Rowley River at $12.5 \mathrm{~km}$ (Tobias et al. 2003). To detect ${ }^{15} \mathrm{~N}$ labels in fish, background average $\delta^{15} \mathrm{~N}$ values were calculated for each station along the salinity 
gradient using measurements of animals collected in 1999 plus those collected from 22 June to 15 July 2000. These background values were subtracted from $\delta^{15} \mathrm{~N}$ averages measured after 15 July 2000 to yield the estimate of ${ }^{15} \mathrm{~N}$ enrichment for each station above a baseline value of $0 \%$. The $95 \%$ confidence limits (CLs) associated with the pre-addition and post-addition station averages were propagated along with the estimate of average ${ }^{15} \mathrm{~N}$ enrichment, and ${ }^{15} \mathrm{~N}$ enrichment values deviating more than 1 propagated 95\% CL above the $0 \%$ baseline value were considered to indicate significant labeling of fish $\mathrm{N}$.

Relatively few samples of pooled stomach contents were collected in 2000, and a slightly different procedure was used in calculating and evaluating ${ }^{15} \mathrm{~N}$ enrichment for fish stomach contents. An average baseline value and 95\% confidence interval was calculated from all pre-addition samples that showed a relatively narrow $\delta^{15} \mathrm{~N}$ range of 7 to $9 \%$. Post-addition ${ }^{15} \mathrm{~N}$ enrichment was considered significant when the ${ }^{15} \mathrm{~N}$ enrichment in individual samples of pooled stomach contents exceeded the $95 \%$ CL above the $0 \%$ baseline.

Power analysis. We conducted a power analysis of the measured fish isotope data to help in the design of future sampling efforts. The objective was to use a minimum number of fish to obtain low-error average values, so that significant isotope differences between averages for sites or years could be detected easily. We considered a program that collects 3 composite samples to estimate average isotope values and associated errors, with several fish pooled to produce each composite sample. We separately randomized all mummichog and all silverside isotope data (listed in Appendix 1) for individuals collected throughout the estuary in the summer of 1999, and then varied the number of animals included in 3 composite samples from 3 to 30 , with higher numbers of pooled individuals expected to decrease errors in the average isotope estimates. Pooled samples were used because it was less expensive to analyze a few composite samples than many individual samples, and because errors shrank more rapidly when pooled samples were used rather than individual samples. Errors associated with the average of the 3 pooled samples were calculated both as standard deviations and $95 \%$ CLs.

\section{RESULTS}

\section{Food sources}

Fish of both species were collected at several stations along the estuary during 30 July to 3 August 1999, with a small-to-large size range represented in each collec- tion; fish sizes were 24 to $89 \mathrm{~mm}$ with fish wet mass ranging from 0.1 to $11.5 \mathrm{~g}$ for mummichogs and 0.1 to $2.9 \mathrm{~g}$ for silversides. Fish CNS isotope results showed no or small gradients along the estuarine transect from 6 to $13 \mathrm{~km}$, i.e. there was no significant difference among average station values for $\delta^{34} \mathrm{~S}$ for either species (Table 1), and only the uppermost and lowermost station averages differed significantly for $\delta^{13} \mathrm{C}$ and $\delta^{15} \mathrm{~N}$ (Table 1). Also, there was no consistent pattern of higher or lower variance (SDs) at down-estuary versus up-estuary stations (Table 1), with SDs varying between 0.4 and $3.2 \%$ (Table 1 ). Only weak relationships were evident for $\delta^{13} \mathrm{C}, \delta^{15} \mathrm{~N}$, or $\delta^{34} \mathrm{~S}$ versus fish size $\left(\mathrm{r}^{2}=\right.$ 0.26 for mummichog total length versus $\delta^{15} \mathrm{~N}, \mathrm{r}^{2}<0.11$ for all other cases).

In contrast to these weak relationships, plots of $\delta^{34} \mathrm{~S}$ versus $\delta^{13} \mathrm{C}$ and $\delta^{34} \mathrm{~S}$ versus $\delta^{15} \mathrm{~N}$ showed strong linear relationships and $\mathrm{r}^{2}$ values of 0.79 and 0.56 , respectively (Fig. 1). Mummichog isotope distributions strongly contrasted those of silversides, i.e. mummichogs had low $\delta^{34} \mathrm{~S}$, low $\delta^{15} \mathrm{~N}$, and high $\delta^{13} \mathrm{C}$ compared to silversides (Fig. 1). Source values estimated from published studies of the Rowley and wider Plum Island estuary generally bracketed the fish isotope values, consistent with 2-source mixing of benthic and planktonic organic matter in food webs supporting the fish. We used a 2-source mixing model with $\delta_{\mathrm{CNS}}$ values to estimate these contributions (see 'Materials and methods') for the 41 mummichogs and 41 silversides listed in Appendix 1 , finding that the overall \% reliance on benthic foods was $58 \pm 5$ (mean $\pm 95 \% \mathrm{CL}$ ) for mummichogs and $32 \pm 3 \%$ for silversides. Estimates of \% benthic food sources using $\delta^{34} \mathrm{~S}$ alone or $\delta^{13} \mathrm{C}$ alone were highly correlated ( $r>0.9$ ) with estimates made with $\delta_{\mathrm{CNS}}$, and there were few significant differences in the results of the mixing models with the $\delta_{\mathrm{CNS}}$ values and the separated $\mathrm{C}, \mathrm{N}$, or $\mathrm{S}$ isotopes. Thus, for the 2 fish species, only carbon isotope calculations for mummichogs gave a significantly different result $(t$-test, $\mathrm{p}<0.05)$ of $66 \%$ benthic food reliance versus the $58 \%$ mean calculated with the $\delta_{\mathrm{CNS}}$ data.

The isotope distributions and mixing model results showed that the 2 species differed strongly in their patterns of reliance on benthic versus planktonic foods, and that this between-species difference was maintained across most of the estuary, with the exception that reliance on benthic foods was low for both species at the uppermost estuary station at $13 \mathrm{~km}$ (Fig. 2). There was always a wide range in calculated individual reliance on benthic foods for mummichogs and for silversides (Fig. 2), consistent with relatively high SDs in the underlying isotope data (Table 1). Wide ranges (20 to $50 \%$ ) occurred among individuals at most stations and were independent of fish size (Fig. 2). 


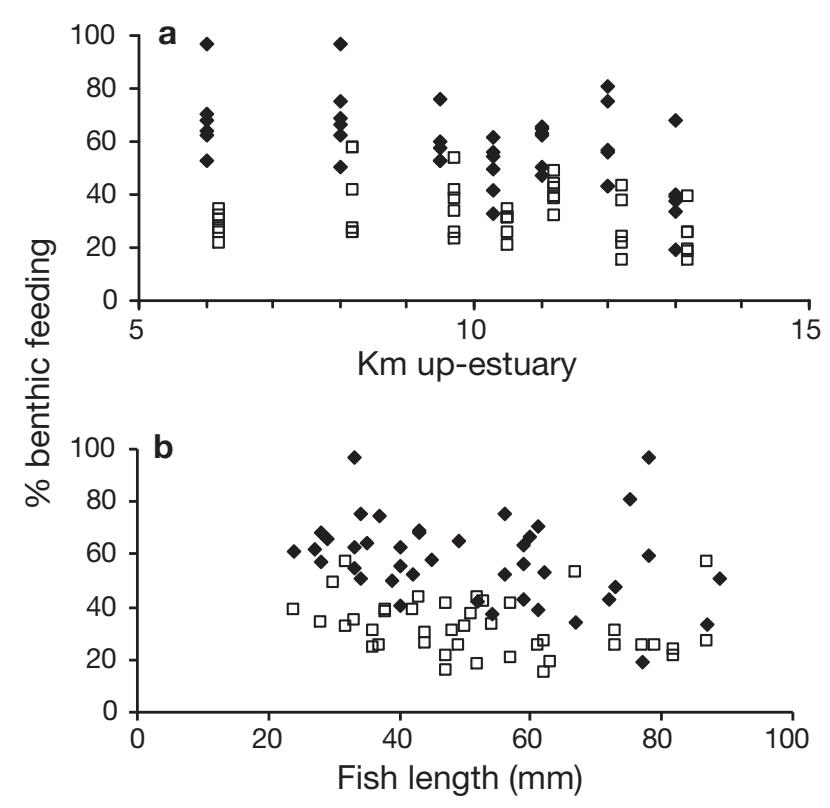

Fig. 2. Fundulus heteroclitus and Menidia menidia. Benthic feeding estimates for individual mummichogs (diamonds) and silversides (squares). Percent benthic feeding was calculated from $\delta_{\text {CNS }}$ values (see 'Materials and methods'). (a) Data by station, with a size range of fish collected at each station;

(b) data by size, with all stations combined

\section{Fish movement}

The ${ }^{15} \mathrm{~N}$ addition in late summer 2000 provided a way to study localization of fish movements, with the highest label concentration observed in fish stomach contents and fish near the site of the tracer addition at $12.5 \mathrm{~km}$ (Fig. 3). Label dispersed with the tides, and
Tobias et al. (2003) considered the area from 10.7 to $14.2 \mathrm{~km}$ to be the isotope-enriched section (see large boxes in Fig. 3). Mummichogs and their stomach contents were not labeled significantly above background outside this area, but there was a low-level enrichment detected in silverside fish and stomach contents much farther down-estuary, all the way to the most marine collection site at $6 \mathrm{~km}$ (Fig. 3).

The label results were consistent with localized movements for both species, with the broadest interpretation that both species showed distinct differences between the ${ }^{15} \mathrm{~N}$-enriched upstream reach (Fig. 3) versus the relatively unenriched downstream reach at 5 to $10 \mathrm{~km}$. A narrower interpretation is that both species showed sharp localization and strong residency in those cases where the label experiment was sensitive and the label distributions could be inferred to show a sharp discontinuity. Thus, mummichogs at $12 \mathrm{~km}$ and $13 \mathrm{~km}$ were much less labeled than those at $14 \mathrm{~km}$, and silversides at $9.5 \mathrm{~km}$ were much less labeled than those at $11 \mathrm{~km}$ (Fig. 3).

However, silversides in the upper estuary did not show the same strong gradient in labeling that was evident in the mummichogs above $11 \mathrm{~km}$ (Fig. 3). Either tides were acting to mix the label fairly evenly in the planktonic prey consumed by silversides in this upper estuary region, or silversides themselves were moving fairly widely through this region to produce the observed even pattern of ${ }^{15} \mathrm{~N}$ enrichment. In either case, the distinct differences in ${ }^{15} \mathrm{~N}$ enrichments between silverside populations in the upper estuary $>11$ $\mathrm{km}$ and the lower estuary $<10 \mathrm{~km}$ (Fig. 3) support the idea that silversides were moderately resident within upper versus lower estuarine reaches.

Table 1. Summary C, N and S isotope data for fish collected along the Rowley River estuary, 30 July to 3 August 1999. Percent benthic feeding was calculated from the cumulative $\delta_{\text {CNS }}$ values, as explained in 'Materials and methods'. Superscripts denote means that are not significantly different $(p>0.05)$ by the $T^{\prime}$ method (Sokal \& Rohlf 1995)

\begin{tabular}{|c|c|c|c|c|c|c|c|c|c|c|c|}
\hline \multirow[t]{2}{*}{ Site $(\mathrm{km})$} & \multirow[t]{2}{*}{$\mathrm{N}$} & & \multirow{2}{*}{$\begin{array}{c}\text { Average } \\
\delta^{15} \mathrm{~N}\end{array}$} & \multirow[b]{2}{*}{$\delta^{34} \mathrm{~S}$} & \multicolumn{3}{|c|}{$-\mathrm{SD}$} & \multicolumn{3}{|c|}{$95 \% \mathrm{CL}$} & \multirow{2}{*}{$\begin{array}{c}\text { Average \% } \\
\text { benthic feeding }\end{array}$} \\
\hline & & $\delta^{13} \mathrm{C}$ & & & $\delta^{13} \mathrm{C}$ & $\delta^{15} \mathrm{~N}$ & $\delta^{34} \mathrm{~S}$ & $\delta^{13} \mathrm{C}$ & $\delta^{15} \mathrm{~N}$ & $\delta^{34} \mathrm{~S}$ & \\
\hline \multicolumn{12}{|c|}{ Mummichogs } \\
\hline 6 & 6 & $-14.8^{\mathrm{a}}$ & $8.5^{\mathrm{c}}$ & $4.7^{\mathrm{e}}$ & 1.3 & 1.2 & 3.2 & 1.1 & 1.0 & 2.6 & 66 \\
\hline 8 & 6 & $-13.8^{\mathrm{a}}$ & $8.2^{\mathrm{c}}$ & $4.1^{\mathrm{e}}$ & 2.3 & 0.9 & 3.0 & 1.8 & 0.7 & 2.4 & 67 \\
\hline 9.5 & 5 & $-15.2^{a, b}$ & $10.0^{\mathrm{c}, \mathrm{d}}$ & $6.1^{\mathrm{e}}$ & 1.1 & 1.4 & 1.3 & 1.0 & 1.3 & 1.2 & 54 \\
\hline 10.3 & 6 & $-16.6^{a, b}$ & $10.2^{\mathrm{c}, \mathrm{d}}$ & $8.1^{\mathrm{e}}$ & 0.9 & 1.6 & 1.4 & 0.7 & 1.3 & 1.1 & 42 \\
\hline 11 & 6 & $-15.7^{\mathrm{a}, \mathrm{b}}$ & $9.4^{\mathrm{c}, \mathrm{d}}$ & $6.5^{\mathrm{e}}$ & 0.9 & 0.9 & 1.4 & 0.7 & 0.7 & 1.1 & 54 \\
\hline 12 & 6 & $-15.8^{\mathrm{a}, \mathrm{b}}$ & $9.9^{\mathrm{c}, \mathrm{d}}$ & $5.9^{\mathrm{e}}$ & 1.4 & 1.3 & 3.2 & 1.1 & 1.0 & 2.6 & 53 \\
\hline 13 & 6 & $-17.7^{\mathrm{b}}$ & $11.6^{\mathrm{d}}$ & $9.1^{\mathrm{e}}$ & 1.6 & 2.0 & 2.3 & 1.3 & 1.6 & 1.8 & 30 \\
\hline \multicolumn{12}{|c|}{ Silversides } \\
\hline 6 & 6 & $-19.9^{f, g}$ & $10.7^{\mathrm{h}}$ & $11.8^{\mathrm{j}}$ & 0.6 & 0.4 & 1.7 & 0.5 & 0.4 & 1.4 & 16 \\
\hline 8 & 6 & $-18.0^{9}$ & $10.7^{\mathrm{h}}$ & $9.9^{\mathrm{j}}$ & 2.4 & 0.8 & 2.7 & 1.9 & 0.7 & 2.2 & 29 \\
\hline 9.5 & 6 & $-18.7^{\mathrm{f}, \mathrm{g}}$ & $11.3^{\mathrm{h}, \mathrm{i}}$ & $9.6^{j}$ & 1.1 & 0.3 & 2.7 & 0.9 & 0.3 & 2.2 & 25 \\
\hline 10.3 & 6 & $-19.6^{f, g}$ & $11.4^{\mathrm{h}, \mathrm{i}}$ & $11.3^{\mathrm{j}}$ & 1.1 & 0.7 & 0.7 & 0.9 & 0.6 & 0.5 & 16 \\
\hline 11 & 6 & $-18.5^{\mathrm{f}, \mathrm{g}}$ & $11.0^{\mathrm{h}, \mathrm{i}}$ & $8.5^{\mathrm{j}}$ & 0.7 & 0.4 & 1.2 & 0.5 & 0.3 & 0.9 & 31 \\
\hline 12 & 5 & $-19.9^{f, g}$ & $12.2^{\mathrm{i}}$ & $10.3^{\mathrm{j}}$ & 1.5 & 0.9 & 2.3 & 1.3 & 0.8 & 2.0 & 16 \\
\hline 13 & 6 & $-20.6^{\mathrm{f}}$ & $12.2^{\mathrm{i}}$ & $11.3^{\mathrm{j}}$ & 1.2 & 1.3 & 1.1 & 1.0 & 1.0 & 0.9 & 10 \\
\hline
\end{tabular}



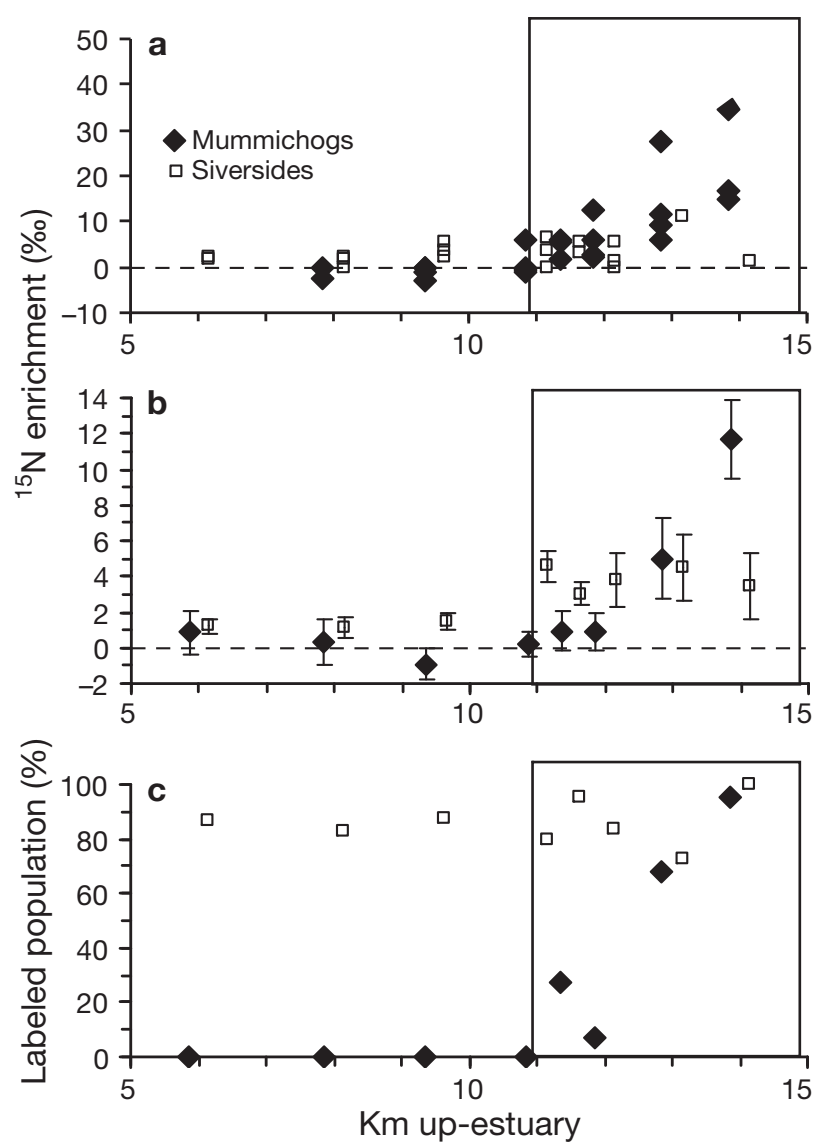

Fig. 3. Fundulus heteroclitus and Menidia menidia. ${ }^{15} \mathrm{~N}$ isotope enrichment in (a) fish stomach contents and (b) fish muscle tissue for samples collected 25 July to 31 August 2000, 2 to $6 \mathrm{wk}$ after initiation of the label addition on 11 July at the $12.5 \mathrm{~km}$ site (error bars: 95\% confidence limits). Values at $0 \%$ represent pre-label baseline; large squares show upper reaches of the estuary with the most isotope enrichment, as determined by Tobias et al. (2003). (c) Proportion of the population sampled that had label in muscle tissue

\section{Power analysis}

Given the considerable scatter in the isotope data for individual fish, 10 to15 fish per composite sample were required to yield a relatively precise average result (Fig. 4). That is, using 3 composite samples of 10 to 15 fish each would allow testing for significant $\mathrm{C}, \mathrm{N}$, or $\mathrm{S}$ isotope differences of $0.5 \%$ or greater between means, because $95 \%$ CLs for the average of the 3 composite samples were $\leq 0.5 \%$ for CNS isotopes (Fig. 4). Table 2 gives coefficients for the power equations used in generating the curves of Fig. 4. Calculation also shows that the error for the overall population can be estimated from the error associated with 3 composite samples using values given in Table 2 as: population error = (error for the 3 composite samples) $\times$ (measured error for the Rowley River fish collected in 1999)/(ax $\left.{ }^{b}\right)$,



Fig. 4. Fundulus heteroclitus and Menidia menidia. Power analysis of isotope data for (a) mummichogs and (b) silversides, showing that the error associated with 3 composite samples decreases as increasing numbers of fish are included in each composite sample. Using 3 composite samples of about 10 fish each gives a high precision error $(\leq 0.5 \%$, $95 \%$ confidence limit) for $\mathrm{C}$ and $\mathrm{N}$ isotopes; comparable $0.5 \%$ errors for $\mathrm{S}$ isotopes, and the combined isotope $\delta_{\mathrm{CNS}}$ value, require more fish per composite sample. Lines: errors calculated from equations in Table 2 for the combined isotopes $\delta_{\text {CNS }}$ (dashed), $\mathrm{S}$ isotopes (solid bold), C isotopes (dot-dash), and $\mathrm{N}$ isotopes (solid thin). For mummichogs, the error curves for $\mathrm{C}$ and $\mathrm{N}$ isotopes are essentially the same and thus do not show as separate curves in the top panel

where $x$ is the number of fish per composite sample and Table 2 gives the measured error for the fish collected in 1999 and the coefficients $a$ and $b$. For example, if 3 composite samples of 10 fish each measured $-15.0,-15.5$, and $-16.0 \%$ for carbon isotopes, the average and SD for the 3 samples would be $-15.5 \pm 0.50 \%$, and the population SD estimated from these results and the carbon isotope equations for mummichog SDs in Table 2 would be $(0.5 \times 1.69) /\left(2.38 \times 10^{-0.8}\right)=2.24 \%$.

\section{DISCUSSION}

Our isotope results were consistent with well-established findings that mummichogs feed more in the benthic food web while silversides feed more on plankton, with both fish species more resident than transient. These findings support using mummichogs and silversides as biosentinel organisms for monitoring ecosystem dynamics in salt marsh systems, with iso- 
Table 2. Coefficients for power equations of the form $y=a x^{b}$ used to estimate the error for isotope averages (error $=y$ as $\mathrm{SD}$ or $95 \%$ confidence limit, CL) calculated for triplicate composite samples with increasing numbers of fish (x) per sample, e.g. 3 samples with 5, 10, or 15 fish in each. Fish data from Appendix 1 were randomized by species for this analysis (n = 41 fish per species), with measured errors (\%) for fish of Appendix 1 also given

\begin{tabular}{|c|c|c|c|c|c|c|c|c|}
\hline & \multicolumn{4}{|c|}{ Equations for SD } & \multicolumn{4}{|c|}{ Equations for $95 \% \mathrm{CL}$} \\
\hline & $\delta^{13} \mathrm{C}$ & $\delta^{15} \mathrm{~N}$ & $\delta^{34} \mathrm{~S}$ & $\delta_{\mathrm{CNS}}$ & $\delta^{13} \mathrm{C}$ & $\delta^{15} \mathrm{~N}$ & $\delta^{34} \mathrm{~S}$ & $\delta_{\mathrm{CNS}}$ \\
\hline \multicolumn{9}{|l|}{ Mummichogs } \\
\hline Constant, a & 2.38 & 2.24 & 4.31 & 8.63 & 2.70 & 2.54 & 4.88 & 9.76 \\
\hline Exponent, b & -0.80 & -0.78 & -0.85 & -0.83 & -0.80 & -0.78 & -0.85 & -0.83 \\
\hline Measured error & 1.69 & 1.64 & 2.75 & 5.68 & 0.52 & 0.50 & 0.84 & 1.74 \\
\hline \multicolumn{9}{|l|}{ Silversides } \\
\hline Constant, a & 1.75 & 1.04 & 2.38 & 4.02 & 1.98 & 1.18 & 2.69 & 4.55 \\
\hline Exponent, b & -0.74 & -0.73 & -0.72 & -0.70 & -0.74 & -0.73 & -0.72 & -0.70 \\
\hline Measured error & 1.52 & 0.91 & 2.08 & 3.81 & 0.46 & 0.28 & 0.64 & 1.74 \\
\hline
\end{tabular}

tope-based feeding assessment providing a functional trophic view of estuarine fish dynamics that can supplement traditional abundance-based structural views of estuarine fish populations. The functional trophic assessment with mummichogs and silversides directly measures the importance of benthic and planktonic food sources in fish diets, and indirectly measures production and relative availability of these food sources at the ecosystem level, as well as overall benthicplanktonic coupling in salt marsh systems.

\section{Food sources}

The feeding biology of mummichogs and silversides was studied in Rowley River during the time of the 2000 label addition experiment (Haines et al. 2000), with detailed stomach content identifications performed for fish from stations along the estuarine salinity gradient from 8 to $14 \mathrm{~km}$. Mummichogs consumed much more detritus, amphipods, and isopods than did silversides. Conversely, silversides consumed more planktonic copepods, shrimp, and insects than did mummichogs. Mummichogs were considered more obligate benthic feeders while silversides were considered more versatile, consuming items from the benthic food web (such as benthic harpacticoid copepods) as well as planktonic items.

Isotope results were very consistent with these results from stomach contents, with fish isotope CNS values falling along mixing lines constructed with benthic and planktonic sources (Fig. 1). Although many more types of food sources are present in the Rowley River and are available to support the food web (Deegan \& Garritt 1997), the linear trends in the isotopes (Fig. 1) indicated clear dominance of 2 aggregated food sources; data would fall in a more triangular pattern if 3 sources were co-dominant, or in a larger polygonal space if $>3$ sources were important. Because of the linear trends in the data (Fig. 1), we used simple 2-source mixing models to interpret isotope data in terms of benthic versus planktonic feeding. The fish CNS isotope distributions also had the same triple isotope contrast measured in older studies of relatively undisturbed salt marsh ecosystems in Georgia and Massachusetts (Peterson et al. 1985, 1986, Peterson \& Howarth 1987), i.e. the main axis of isotope resolution was between benthic foods that had relatively high $\mathrm{C}$ isotope values and low $\mathrm{N}$ and $\mathrm{S}$ isotope values versus planktonic foods with lower $\mathrm{C}$ isotope values but higher $\mathrm{N}$ and higher $\mathrm{S}$ isotope values. This same triple isotope contrast was also found in broad outline in an earlier study (Deegan \& Garritt 1997) of the food web in the Plum Island Sound system, to which the Rowley River system belongs.

However, these same isotope contrasts are not found in all salt marsh systems. For example, Wozniak et al. (2006) documented that the benthic primary producer Spartina alterniflora can have much higher $\delta^{34} \mathrm{~S}$ values (to $17 \%$ ) in smaller New England salt marshes, so that not all marshes have the same triple isotope contrast as observed in this and earlier studies by Peterson and colleagues (Peterson et al. 1985, 1986, Peterson \& Howarth 1987). Geographic variation in Spartina $\mathrm{N}$ and $\mathrm{S}$ isotope values has also been documented previously (Currin et al. 1995, Stribling et al. 1998, Wainright et al. 2000), and for $\mathrm{S}$ isotopes may be related to variations in sulfate reduction and sulfide cycling (Peterson et al. 1986, Peterson \& Howarth 1987, Stribling et al. 1998). Because food source isotope values evidently can vary widely in salt marsh systems, isotope monitoring should include sampling of local foods.

Distinguishing the importance of individual benthic foods also was difficult in the present study. Besides Spartina, benthic foods possibly important in these salt marsh systems include sedimentary microalgae that 
are often enriched in ${ }^{13} \mathrm{C}$ versus phytoplankton (Haines 1976, Currin et al. 1995, 2003, Page 1997, Oakes et al. 2005). Of particular note are reports for mudflat ecosystems where diatoms and benthic bivalves (Macoma balthica) can have $\delta^{13} \mathrm{C}$ values of -10 to $-14 \%$ (Incze et al. 1982, Schwinghamer et al. 1983), i.e. values in the range estimated here for benthic sources with more extreme isotope values than measured for Spartina. Better techniques for isolating benthic microalgae are needed so that CNS isotopes can be measured routinely for these likely important food resources. Resolving the organic food web contributions of Spartina versus benthic microalgae particularly may depend on better techniques for isolating clean samples of organic sulfur for $\delta^{34} \mathrm{~S}$ analysis. Small sulfidic pyrite grains $<5 \mu \mathrm{m}$ in diameter are common inorganic constituents of estuarine sediments (Howarth 1979) and can contaminate the organic sulfur analyses of estuarine microalgae (Currin et al. 2003).

\section{Fish movement}

Our results generally were consistent with previously documented small-scale movements of mummichogs and silversides in salt marsh systems, although both species may move out of these shallow upper portions of the estuary into deeper sound waters during the winter (Warkentine \& Rachlin 1989, Griffin \& Valiela 2001). Animals sampled late in the summer should integrate and reflect the current year of food web production in their tissues, although the largest animals collected may be 1+ yr old and undoubtedly retain some tissue CNS from previous years. Logan et al. (2006) studied tissue turnover in juvenile mummichogs of the size sampled in our study and showed that $\mathrm{N}$ isotopes largely equilibrated with new diets in 1 to 2 mo, the time frame of fish sampling after initiation of the ${ }^{15} \mathrm{~N}$ enrichment experiment in 2000. The localized movements indicated by the tracer addition experiment were consistent with previous tagging studies for mummichogs that showed localized summer movements on the order of $1 \mathrm{~km}$ or less (Lotrich 1975, Meredith \& Lotrich 1979). Tagging studies conducted in the Rowley estuary in 1998 also showed that most (>90\%) recaptured mummichogs were caught within $100 \mathrm{~m}$ of the site of tagging (Sweeney et al. 1998), although those studies also showed that other mummichogs move up and down main channels and across the marsh landscape through mosquito ditches and flooded salt pannes. Mummichogs in nearby Maine marshes also show very localized movements (McMahon et al. 2005).

The movements of silversides are less well known from previous work. Our results indicated rather dis- tinct populations of down-estuary and up-estuary silversides. Tobias et al. (2003) estimated isotope values of phytoplankton and benthic microalgae during the 2000 tracer addition experiment, finding higher values in the up-estuary tracer nutrient addition zone and much lower values down-estuary, where inputs of unlabeled nutrients were also important. Relatively high $\delta^{15} \mathrm{~N}$ values near $250 \%$ were estimated by Tobias et al. (2003) for some upper estuary phytoplankton samples, and down-estuary export of this labeled phytoplankton could have led to the slightly elevated $\delta^{15} \mathrm{~N}$ values observed at 6 to $9.5 \mathrm{~km}$ for planktonfeeding silversides (Fig. 3). This phytoplankton export is consistent with the relatively large $(>5 \mathrm{~km})$ tidal excursions of the water masses in the Rowley system. Thus, relatively small label presence in the downestuary silversides did not necessarily result from fish migration to sites near the point of label addition in the upper estuary; rather, down-estuary silversides could be largely resident but become slightly enriched by consuming materials exported from upper reaches of the estuary.

Given the conclusion that both fish species are composed of largely resident populations, with the caveat that up-estuary populations in shallow portions of the ecosystem undoubtedly move downstream if water drains completely at low tide, it was interesting that there was only a modest gradient in fish $\mathrm{C}$ and $\mathrm{N}$ isotopes along the estuarine transect, and no gradient in $\mathrm{S}$ isotopes. Abundant marine sulfate provides a uniform starting point for $\mathrm{S}$ isotope distributions throughout saline ( $>2 \mathrm{psu}$ ) portions of estuaries leading to the lack of strong S isotope gradients (Fry 2002, 2007). In contrast, estuarine biogeochemistry usually produces stronger $\mathrm{C}$ and $\mathrm{N}$ isotope gradients that covary with salinity (Fry 2002). There were some significant differences among average fish $\mathrm{C}$ and $\mathrm{N}$ isotope values along the estuarine gradient (Table 1), but relatively uniform salinities may have accounted for the lack of stronger $\mathrm{C}$ and $\mathrm{N}$ isotope gradients. Tobias et al. (2003) compiled salinity data for the summer of 2000, with the 6 to $13 \mathrm{~km}$ stations all sharing moderate mesohaline salinities averaging about 15 to $30 \mathrm{psu}$. Also, the marshes of the Rowley estuary are dominated by Spartina spp. for most of the length of the estuary, especially from $12 \mathrm{~km}$ seawards, but some Spartina also extends into the upper reaches of the estuary to $14.5 \mathrm{~km}$ (Tobias et al. 2003). The freshwater runoff from the upland portion of the Rowley River is quite small, with low flows in the summer months of our study (e.g. $0.02 \mathrm{~m}^{-3} \mathrm{~s}^{-1}$ in the summer of 2000; Tobias et al. 2003), so that marine influences remain relatively strong through most of the estuary. Overall, the relatively uniform salinity and vegetation along the estuarine transect may largely be responsible for the lack of 
strong and consistent along-estuary $\mathrm{C}$ and $\mathrm{N}$ isotope variation in fish.

The fish isotope distributions showed a wide variance, indicating a wide range in individual feeding strategies (Fig. 2). Wide ranges in fish isotope compositions were observed also in marshes of Lake Okeechobee, Florida (Fry et al. 1999), and were explained in spatial terms as specialized feeding on localized foods that themselves differ widely in isotope values. A similar explanation is that the Rowley River mummichogs and silversides exhibit localized feeding strategies, with varying degrees of marsh access. Silversides showed strong CNS isotope variation among individuals that was comparable to the mummichog isotope variation (Table 1). One explanation for this wide variation is that some silversides enter marshes and feed extensively in certain localized areas, while other silversides confine their feeding much more to open water areas. Studies that trap fish exiting the marsh platform on falling tides could test the inferred use of marsh foods. It is also possible that some silversides remain in channels but position themselves at points where marsh run-off is particularly strong or weak.

\section{Power analysis}

Our power analysis was relatively simple to perform using data for individual fish. The between-individual variation controls the results of the power analysis, and monitoring should include some collections of individuals to check that the coefficients of the power equations (Table 2) apply to the local system under study. Individual isotope variation among mummichogs in our study was very similar to that documented by Currin et al. (2003) in studies of New Jersey mummichogs, with $\mathrm{C}, \mathrm{N}$, and $\mathrm{S}$ standard errors associated with mean values averaging respectively $0.30,0.19$, and $0.47 \%$ in that study versus $0.26,0.26$, and $0.43 \%$ in our study. This similarity may indicate some generality across different salt marsh systems for the equations in Table 2. The higher variability in the $\mathrm{S}$ data versus the $\mathrm{C}$ and $\mathrm{N}$ data requires larger numbers of fish per sample for the same level of precision, i.e. about 15 fish per sample for $\mathrm{S}$ versus 10 fish per sample for $\mathrm{C}$ or $\mathrm{N}$ to obtain $0.5 \%$ precision as $95 \%$ CL for 3 composite samples (Fig. 4).

To estimate average isotope values of fish, Wozniak et al. (2006) used 3 to 6 samples of composites composed of 5+ individual mummichogs; another study of estuarine animals with CNS isotopes used 3 composite samples each composed of 10 animals (Wissel \& Fry 2005). In these cases, the total number of individuals per site was 30 to 60 animals. Our power analysis indicates that obtaining 3 composite samples of 10 to 15 animals per sample for each collection point should allow testing for significant differences of 0.5 to $1 \%$ among site or seasonal averages. The power analysis in Fig. 4 is based on pooling fish from all locations throughout the estuary (Appendix 1), mostly because using the combined data generates a conservative (maximum) number of fish needed per composite sample. When fish isotope variation at single locations is smaller, the number of fish per sample could be reduced. For example, if only animals from mid-estuarine 9 to $11 \mathrm{~km}$ stations with most similar isotope values (Table 1) were used in the power analyses, numbers of fish needed per composite sample would be 70 to $80 \%$ of those projected in Fig. 4. Using composite samples in monitoring programs allows rapid and cost-effective testing for changes in isotope averages, and as described in the Results can also allow some estimate of isotope variation among individuals when several composites are collected together as replicates.

\section{CONCLUSIONS}

There are several general conclusions arising from this and previous studies that can help guide future stable isotope monitoring studies of salt marsh fish. First, fish isotopes need interpretation within the framework of possible basal food resources (plankton, Spartina, and benthic microalgae) supporting the fish food web. This becomes important when trying to interpret whether changes in fish isotopes reflect changing production and availability of sources at the whole ecosystem level, or whether productivity and availability of basal foods is constant, and it is only the food source isotope values that are changing due to lowerlevel background changes in estuarine hydrobiogeochemistry and ecosystem metabolism (Fry 2002, Kaldy et al. 2005, Gustafson et al. 2007). For these reasons, local collections of plankton, Spartina, and benthic microalgae generally should accompany fish collections. Bivalves collected along the marsh-open water in salt marsh systems can conveniently help define isotopes in local planktonic and benthic sources (Peterson et al. 1985, Fry 2007), and collections of dissolved inorganic carbon, shell carbonates, macroalgae, and sulfate also can be used with current models to help estimate CNS isotope distributions in end member sources (Stribling \& Cornwell 1997, Wainright et al. 2000). Some sampling of individual fish also seems warranted to check for food sources with more extreme isotope values (see 'Materials and methods') that are missed in the routine sampling. Also, isotope variability among individual fish may itself be a useful measure of environmental complexity and habitat restoration, and is recommended where budgets allow. Overall, using composite samples is cheaper and adequate for following 
changes in average ecosystem conditions that is often of most interest in monitoring programs, but some sampling of individuals should be included to help monitor isotope variability.

The simplest isotope mixing patterns in salt marsh estuaries have been detected when sampling was done in mesohaline, lower estuary, main stem channels (Peterson et al. 1986, Peterson \& Howarth 1987, Stribling \& Cornwell 1997, this study). Separate mixing models may need to be developed for upper estuary or hydrologically isolated marshes where especially mummichogs have lower $\delta^{13} \mathrm{C}$ values (Deegan \& Garritt 1997, Wainright et al. 2000, Currin et al. 2003, McMahon et al. 2005) than those reported here for the mesohaline sections of the Rowley River. Salt marsh systems are supported by abundant phytoplankton productivity as well as benthic Spartina and microalgal production, and for this reason, monitoring collections routinely should include plankton-feeding fish species such as silversides. Collections of plankton-feeding fish together with benthic-feeding fish should allow construction of robust planktonic-benthic mixing models for assessing changes in salt marsh ecosystem function.

Acknowledgements. Dan Becker helped in the collection of the fish samples from the Rowley River estuary. This work was supported by Louisiana SeaGrant Projects R/CEH-13 and R-EFH-07, NOAA MULTISTRESS award 16OP2670, and NSF award DEB 9815598 and BES SGER award 0553138-001.

\section{LITERATURE CITED}

Able KW, Fahay MP (1998) The first year in the life of estuarine fishes in the middle Atlantic Bight. Rutgers University Press, New Brunswick, NJ

Barrie A, Prosser SJ (1996) Automated analysis of lightelement stable isotopes by isotope ratio mass spectrometry. In: Boutton TW, Yamasaki S (eds) Mass spectrometry of soils. Marcel Dekker, New York, p 1-46

Brand WA (1996) High precision isotope ratio monitoring techniques in mass spectrometry. J Mass Spectrom 31: 225-235

Connolly RM, Guest MA, Melville AJ, Oakes JM (2004) Sulfur stable isotopes separate producers in marine food-web analysis. Oecologia 138:161-167

Currin CA, Newell SY, Paerl HW (1995) The role of standing dead Spartina alterniflora and benthic microalgae in salt marsh foods webs: considerations based on multiple stable isotope analysis. Mar Ecol Prog Ser 121:99-116

Currin CA, Wainright SC, Able KW, Weinstein MP, Feller CM (2003) Determination of food web support and trophic position of the mummichog, Fundulus heteroclitus, in New Jersey smooth cordgrass (Spartina alterniflora), common reed (Phragmites australis), and restored salt marshes. Estuaries 26:495-510

> D'Avanzo C, Valiela I (1990) Use of detrital foods and assimilation of nitrogen by coastal detritivores. Estuaries 13:20-24

> Deegan LA, Garritt RH (1997) Evidence for spatial variability in estuarine food webs. Mar Ecol Prog Ser 147:31-47

Dittel AI, Epifanio CE, Fogel ML (2006) Trophic relationships of juvenile blue crabs (Callinectes sapidus) in estuarine habitats. Hydrobiologia 568:379-390

Fry B (2002) Conservative mixing of stable isotopes across estuarine salinity gradients: a conceptual framework for monitoring watershed influences on downstream fisheries production. Estuaries 25:264-271

Fry B (2006) Stable isotope ecology. Springer, New York

- Fry B (2007) Coupled N, C, and S isotope measurements using a dual column GC system. Rapid Commun Mass Spectrom 21:750-756

Fry B, Mumford PL, Tam F, Fox DD, Warren GL, Havens KE, Steinman AL (1999) Trophic position and individual feeding histories of fish from Lake Okeechobee, Florida. Can J Fish Aquat Sci 56:590-600

Gerking SD (1994) Feeding ecology of fish. Academic Press, New York

Griffin MPA, Valiela I (2001) $\delta^{15} \mathrm{~N}$ isotope studies of life history and trophic position of Fundulus heteroclitus and Menidia menidia. Mar Ecol Prog Ser 214:299-305

Gustafson L, Showers W, Kwak T, Levine J, Stoskopf M (2007) Temporal and spatial variability in stable isotope compositions of a freshwater mussel: implications for biomonitoring and ecological studies. Oecologia 152:140-150

Haines EB (1976) Relation between the stable carbon isotope composition of fiddler crabs, plants, and soils in a salt marsh. Limol Oceanogr 21:880-883

Haines J, Cieri M, Deegan LA (2000) Food choice convergence of benthic and planktonic fishes along an estuarine geomorphologic gradient. Undergraduate thesis, Connecticut College, New London, CT

Howarth RW (1979) Pyrite - its rapid formation in a salt marsh and its importance in ecosystem metabolism. Science 203: $49-51$

Hughes JE, Deegan LA, Peterson BJ, Holmes RM, Fry B (2000) Nitrogen flow through the food web in the oligohaline zone of a New England estuary. Ecology 81:433-452

Incze LS, Mayer LM, Sherr EB, Macko SA (1982) Carbon inputs to bivalve mollusks: a comparison of two estuaries. Can J Fish Aquat Sci 39:1348-1352

Kaldy JE, Cifuentes LA, Brock D (2005) Using stable isotope analyses to assess carbon dynamics in a shallow subtropical estuary. Estuaries 28:86-95

Kneib RT, Stiven AE, Haines EB (1980) Stable carbon isotope ratios in Fundulus heteroclitus (L.) muscle tissue and gut contents from a North Carolina salt marsh. J Exp Mar Biol Ecol 46:89-98

Logan J, Haas H, Deegan LA, Gaines E (2006) Turnover rates of nitrogen stable isotopes in the salt marsh mummichog, Fundulus heteroclitus, following a laboratory diet switch. Oecologia 147:391-395

Lotrich VA (1975) Summer home range and movements of Fundulus heteroclitus (Pisces: Cyprinodontidae) in a tidal creek. Ecology 56:191-198

McMahon KW, Johnson BJ, Ambrose WG (2005) Diet and movement of the killifish, Fundulus heteroclitus, in a Maine salt marsh assessed using gut contents and stable isotopes. Estuaries 28:966-973

Meredith WH, Lotrich VA (1979) Population dynamics of a tidal creek population of Fundulus heteroclitus (Linnaeus). Estuar Coast Mar Sci 8:99-118

Murdy EO, Birdsong RS, Musick JA (1997) Fishes of the Chesapeake Bay. Smithsonian Institution Press, Washington, DC

Oakes JM, Revill AT, Connolly RM, Blackburn SI (2005) Measuring carbon isotope ratios of microphytobenthos using compound-specific stable isotope analysis of phytol. Limnol Oceanogr Methods 3:511-519

Peterson BJ, Fry B (1987) Stable isotopes in ecosystem stud- 
ies. Annu Rev Ecol Syst 18:293-320

Peterson BJ, Howarth RW (1987) Sulfur, carbon, and nitrogen isotopes used to trace organic matter flow in the salt-marsh estuaries of Sapelo Island, Georgia. Limnol Oceanogr 32: 1195-1213

Peterson BJ, Howarth RW, Garritt RH (1985) Multiple stable isotopes used to trace the flow of organic matter in estuarine food webs. Science 227:1361-1363

Peterson BJ, Howarth RW, Garritt RH (1986) Sulfur and carbon isotopes as tracers of salt-marsh organic matter flow. Ecology 67:865-874

Schmidt SN, Olden JD, Solomon CT, Vander Zanden MJ (2007) Quantitative approaches to the analysis of stable isotope food web data. Ecology 88:2793-2802

Schwinghamer P, Tan FC, Gordon DC Jr (1983) Stable carbon isotope studies on the Pecks Cove mudflat ecosystem in the Cumberland Basin, Bay of Fundy. Can J Fish Aquat Sci 40:262-272

Sokal RR, Rohlf FJ (1995) Biometry. WH Freeman \& Co, New York

Stribling MM, Cornwell JC (1997) Identification of important primary producers in a Chesapeake Bay tidal creek system using stable isotopes of carbon and sulfur. Estuaries 20: $77-85$

Stribling JM, Cornwell JC, Currin C (1998) Variability in stable sulfur isotopic ratios in Spartina alterniflora. Mar Ecol Prog Ser 166:73-81

Sweeney J, Deegan LA, Garritt R (1998) Population size and site fidelity of Fundulus heteroclitus in a macrotidal saltmarsh creek. Biol Bull (Woods Hole) 195:238-239
Talley DM (2000) Ichthyofaunal utilization of newly-created versus natural salt marsh creeks in Mission Bay, California. Wetl Ecol Manag 8:117-132

Tobias CR, Cieri M, Peterson BJ, Deegan LA, Vallino J, Hughes J (2003) Processing watershed-derived nitrogen in a well-flushed New England estuary. Limnol Oceanogr 48:1766-1778

Vander Zanden JM, Rasmussen JB (2001) Variation in $\delta^{15} \mathrm{~N}$ and $\delta^{13} \mathrm{C}$ trophic fractionation: implications for aquatic food web studies. Limnol Oceanogr 46:2061-2066

Wainright SC, Weinstein MP, Able KW, Currin CA (2000) Relative importance of benthic microalgae, phytoplankton and the detritus of smooth cordgrass Spartina alterniflora and the common reed Phragmites australis to brackishmarsh food webs. Mar Ecol Prog Ser 200:77-91

Warkentine BE, Rachlin JW (1989) Winter offshore diet of the Atlantic silverside, Menidia menidia. Copeia 1989: 195-198

Williams DG, Evans RD, West JB, Ehleringer JR (2007) Applications of stable isotope measurements for early-warning detection of ecological change. In: Dawson TE, Siegwolf RT (eds) Stable isotopes as indicators of ecological change. Elsevier, Amsterdam, p 383-398

Wissel B, Fry B (2005) Tracing Mississippi River influences in estuarine food webs of coastal Louisiana. Oecologia 144: 659-672

Wozniak AS, Roman CT, Wainright SC, McKinney RA, James-Pirri MJ (2006) Monitoring food web changes with tidal restoration of salt marshes: a carbon stable isotope approach. Estuaries Coasts 29:568-578

Appendix 1. Size and isotope values of fish collected in the Rowley River, 30 July to 3 August 1999

\begin{tabular}{|c|c|c|c|c|c|c|c|c|}
\hline No. & $\begin{array}{c}\text { Field } \\
\text { sample no. }\end{array}$ & $\begin{array}{c}\text { Total } \\
\text { length }(\mathrm{mm})\end{array}$ & Wet mass (g) & $\begin{array}{l}\text { Collection site } \\
\text { (river km) }\end{array}$ & $\delta^{13} \mathrm{C}_{\mathrm{VPDB}}$ & $\delta^{15} \mathrm{~N}_{\mathrm{AIR}}$ & $\delta^{34} \mathrm{~S}_{\mathrm{VCDT}}$ & $\delta_{\mathrm{CNS}}$ \\
\hline \multicolumn{9}{|c|}{ Fundulus heteroclitus } \\
\hline 1 & 73 & 27 & 0.1 & 6.0 & -16.0 & 9.0 & 5.4 & 30.4 \\
\hline 2 & 74 & 33 & 0.5 & 6.0 & -12.4 & 6.4 & -0.8 & 18.0 \\
\hline 3 & 75 & 35 & 0.5 & 6.0 & -15.1 & 7.7 & 6.9 & 29.7 \\
\hline 4 & 76 & 42 & 1.0 & 6.0 & -16.0 & 9.4 & 8.5 & 33.8 \\
\hline 5 & 77 & 43 & 1.5 & 6.0 & -14.7 & 8.9 & 4.8 & 28.3 \\
\hline 6 & 78 & 61 & 3.2 & 6.0 & -14.5 & 9.4 & 3.4 & 27.3 \\
\hline 7 & 61 & 33 & 0.6 & 8.0 & -16.3 & 8.3 & 5.6 & 30.2 \\
\hline 8 & 62 & 37 & 0.8 & 8.0 & -13.1 & 7.9 & 4.9 & 25.9 \\
\hline 9 & 63 & 43 & 0.9 & 8.0 & -13.8 & 7.6 & 6.5 & 27.9 \\
\hline 10 & 64 & 60 & 2.6 & 8.0 & -14.2 & 9.8 & 4.8 & 28.8 \\
\hline 11 & 65 & 78 & 6.0 & 8.0 & -11.8 & 7.6 & -1.3 & 18.1 \\
\hline 12 & 66 & 89 & 11.5 & 8.0 & -18.2 & 9.2 & 7.1 & 34.4 \\
\hline 13 & 1 & 34 & 0.3 & 9.5 & -13.9 & 7.7 & 4.0 & 25.6 \\
\hline 14 & 3 & 45 & 1.1 & 9.5 & -15.7 & 10.1 & 6.1 & 31.9 \\
\hline 15 & 4 & 56 & 2.1 & 9.5 & -15.8 & 10.5 & 7.6 & 33.8 \\
\hline 16 & 5 & 62 & 3.1 & 9.5 & -16.3 & 11.6 & 5.8 & 33.7 \\
\hline 17 & 6 & 78 & 6.7 & 9.5 & -14.1 & 10.3 & 6.8 & 31.2 \\
\hline 18 & 49 & 24 & 0.1 & 10.3 & -15.6 & 7.8 & 7.4 & 30.7 \\
\hline 19 & 50 & 33 & 0.4 & 10.3 & -16.1 & 9.6 & 7.4 & 33.1 \\
\hline 20 & 51 & 39 & 0.7 & 10.3 & -16.5 & 10.1 & 8.1 & 34.7 \\
\hline 21 & 52 & 52 & 1.7 & 10.3 & -17.4 & 11.1 & 9.2 & 37.6 \\
\hline 22 & 53 & 59 & 2.5 & 10.3 & -16.2 & 10.0 & 6.4 & 32.6 \\
\hline 23 & 54 & 87 & 8.6 & 10.3 & -18.0 & 12.5 & 10.3 & 40.8 \\
\hline 24 & 13 & 29 & 0.3 & 11.0 & -15.6 & 8.6 & 4.8 & 29.0 \\
\hline 25 & 14 & 34 & 0.5 & 11.0 & -16.6 & 9.7 & 8.2 & 34.5 \\
\hline 26 & 15 & 40 & 0.7 & 11.0 & -14.7 & 9.4 & 6.2 & 30.3 \\
\hline 27 & 16 & 49 & 1.4 & 11.0 & -15.0 & 8.6 & 5.8 & 29.4 \\
\hline
\end{tabular}


Appendix 1 (continued)

\begin{tabular}{|c|c|c|c|c|c|c|c|c|}
\hline No. & $\begin{array}{c}\text { Field } \\
\text { sample no. }\end{array}$ & $\begin{array}{c}\text { Total } \\
\text { length }(\mathrm{mm})\end{array}$ & Wet mass (g) & $\begin{array}{l}\text { Collection site } \\
\quad \text { (river km) }\end{array}$ & $\delta^{13} \mathrm{C}_{\mathrm{VPDB}}$ & $\delta^{15} \mathrm{~N}_{\mathrm{AIR}}$ & $\delta^{34} \mathrm{~S}_{\mathrm{VCDT}}$ & $\delta_{\mathrm{CNS}}$ \\
\hline 28 & 17 & 59 & 2.6 & 11.0 & -15.2 & 8.9 & 5.8 & 29.9 \\
\hline 29 & 18 & 73 & 5.6 & 11.0 & -16.8 & 10.9 & 8.0 & 35.7 \\
\hline 30 & 25 & 28 & 0.2 & 12.0 & -17.0 & 9.8 & 5.5 & 32.3 \\
\hline 31 & 26 & 40 & 0.7 & 12.0 & -15.8 & 9.7 & 7.2 & 32.7 \\
\hline 32 & 27 & 56 & 2.1 & 12.0 & -14.0 & 8.4 & 3.4 & 25.8 \\
\hline 33 & 28 & 59 & 2.7 & 12.0 & -16.5 & 11.7 & 9.0 & 37.2 \\
\hline 34 & 29 & 72 & 5.0 & 12.0 & -17.1 & 10.9 & 9.2 & 37.2 \\
\hline 35 & 30 & 75 & 5.8 & 12.0 & -14.0 & 8.8 & 1.0 & 23.8 \\
\hline 36 & 37 & 28 & 0.2 & 13.0 & -14.7 & 8.0 & 5.4 & 28.2 \\
\hline 37 & 38 & 40 & 0.7 & 13.0 & -18.5 & 10.8 & 9.0 & 38.2 \\
\hline 38 & 39 & 54 & 1.8 & 13.0 & -18.0 & 12.2 & 8.9 & 39.2 \\
\hline 39 & 40 & 61 & 3.0 & 13.0 & -17.6 & 11.9 & 9.2 & 38.7 \\
\hline 40 & 41 & 67 & 3.9 & 13.0 & -18.1 & 12.9 & 9.5 & 40.4 \\
\hline 41 & 42 & 77 & 6.6 & 13.0 & -19.5 & 13.8 & 12.5 & 45.8 \\
\hline \multicolumn{9}{|c|}{ Menidia menidia } \\
\hline 1 & 79 & 32 & 0.3 & 6.0 & -20.4 & 10.2 & 10.5 & 41.1 \\
\hline 2 & 80 & 33 & 0.2 & 6.0 & -20.1 & 10.5 & 9.5 & 40.1 \\
\hline 3 & 81 & 44 & 0.6 & 6.0 & -20.2 & 10.6 & 10.8 & 41.7 \\
\hline 4 & 82 & 47 & 0.7 & 6.0 & -20.5 & 10.7 & 13.7 & 44.8 \\
\hline 5 & 83 & 62 & 1.3 & 6.0 & -19.1 & 10.6 & 13.2 & 42.9 \\
\hline 6 & 84 & 77 & 2.4 & 6.0 & -19.1 & 11.5 & 12.9 & 43.5 \\
\hline 7 & 67 & 32 & 0.1 & 8.0 & -14.9 & 10.8 & 6.4 & 32.1 \\
\hline 8 & 68 & 37 & 0.2 & 8.0 & -20.4 & 10.6 & 12.3 & 43.3 \\
\hline 9 & 69 & 49 & 0.6 & 8.0 & -18.5 & 10.9 & 8.5 & 37.8 \\
\hline 10 & 70 & 57 & 1.1 & 8.0 & -19.7 & 11.5 & 12.2 & 43.5 \\
\hline 11 & 71 & 73 & 2.0 & 8.0 & -19.2 & 11.3 & 12.4 & 42.9 \\
\hline 12 & 72 & 87 & 2.9 & 8.0 & -15.2 & 9.2 & 7.7 & 32.1 \\
\hline 13 & 7 & 38 & 0.3 & 9.5 & -18.4 & 11.1 & 9.3 & 38.9 \\
\hline 14 & 8 & 44 & 0.4 & 9.5 & -20.2 & 11.5 & 11.6 & 43.3 \\
\hline 15 & 9 & 47 & 0.4 & 9.5 & -17.6 & 11.1 & 9.1 & 37.7 \\
\hline 16 & 10 & 54 & 0.9 & 9.5 & -19.0 & 11.8 & 9.8 & 40.6 \\
\hline 17 & 11 & 67 & 1.4 & 9.5 & -17.4 & 11.0 & 5.1 & 33.5 \\
\hline 18 & 12 & 82 & 2.5 & 9.5 & -19.6 & 11.5 & 13.0 & 44.2 \\
\hline 19 & 55 & 28 & 0.1 & 10.3 & -19.0 & 10.2 & 11.1 & 40.3 \\
\hline 20 & 56 & 36 & 0.2 & 10.3 & -19.6 & 11.5 & 10.4 & 41.5 \\
\hline 21 & 57 & 48 & 0.5 & 10.3 & -19.1 & 11.0 & 11.4 & 41.4 \\
\hline 22 & 58 & 57 & 1.1 & 10.3 & -21.8 & 11.4 & 12.0 & 45.2 \\
\hline 23 & 59 & 61 & 1.3 & 10.3 & -19.1 & 12.3 & 12.1 & 43.5 \\
\hline 24 & 60 & 73 & 1.9 & 10.3 & -18.8 & 11.8 & 10.8 & 41.4 \\
\hline 25 & 19 & 30 & 0.1 & 11.0 & -17.6 & 10.5 & 6.9 & 35.0 \\
\hline 26 & 20 & 38 & 0.3 & 11.0 & -18.6 & 11.4 & 8.7 & 38.7 \\
\hline 27 & 21 & 42 & 0.4 & 11.0 & -18.7 & 11.0 & 9.0 & 38.6 \\
\hline 28 & 22 & 50 & 0.6 & 11.0 & -19.4 & 11.3 & 10.3 & 41.0 \\
\hline 29 & 23 & 52 & 0.8 & 11.0 & -17.9 & 10.7 & 8.4 & 36.9 \\
\hline 30 & 24 & 53 & 0.8 & 11.0 & -18.6 & 11.3 & 7.7 & 37.6 \\
\hline 31 & 32 & 36 & 0.2 & 12.0 & -20.4 & 12.9 & 10.5 & 43.9 \\
\hline 32 & 33 & 43 & 0.5 & 12.0 & -18.5 & 11.2 & 7.4 & 37.1 \\
\hline 33 & 34 & 51 & 0.7 & 12.0 & -18.6 & 11.9 & 8.7 & 39.2 \\
\hline 34 & 35 & 62 & 1.2 & 12.0 & -22.1 & 11.9 & 13.2 & 47.2 \\
\hline 35 & 36 & 82 & 2.9 & 12.0 & -19.7 & 13.3 & 11.8 & 44.9 \\
\hline 36 & 43 & 24 & 0.1 & 13.0 & -19.0 & 9.9 & 9.9 & 38.7 \\
\hline 37 & 44 & 37 & 0.2 & 13.0 & -20.7 & 12.4 & 10.4 & 43.5 \\
\hline 38 & 45 & 47 & 0.6 & 13.0 & -22.3 & 11.9 & 12.7 & 47.0 \\
\hline 39 & 46 & 52 & 0.8 & 13.0 & -21.5 & 12.3 & 12.3 & 46.1 \\
\hline 40 & 47 & 63 & 1.3 & 13.0 & -20.3 & 13.7 & 11.6 & 45.7 \\
\hline 41 & 48 & 79 & 2.5 & 13.0 & -19.6 & 12.8 & 11.1 & 43.5 \\
\hline
\end{tabular}

Editorial responsibility: Tom Minello, Galveston, Texas, USA
Submitted: December 12, 2007; Accepted: July 9, 2008

Proofs received from author(s): September 29, 2008 